This is an electronic reprint of the original article. This reprint may differ from the original in pagination and typographic detail.

Author(s): Virtanen, Aija

Title: $\quad$ The multivoicedness of written documentation: An international nursing student documenting in a second language

Year: $\quad 2017$

Version:

Please cite the original version:

Virtanen, A. (2017). The multivoicedness of written documentation: An international nursing student documenting in a second language. European Journal of Applied Linguistics, 5(1), 115-140. https://doi.org/10.1515/eujal-2015-0015

All material supplied via JYX is protected by copyright and other intellectual property rights, and duplication or sale of all or part of any of the repository collections is not permitted, except that material may be duplicated by you for your research use or educational purposes in electronic or print form. You must obtain permission for any other use. Electronic or print copies may not be offered, whether for sale or otherwise to anyone who is not an authorised user. 


\section{Aija Virtanen* \\ The multivoicedness of written documentation: An international nursing student documenting in a second language}

\section{Introduction}

Finland used to be a country that sent workers abroad instead of recruiting an international workforce, a trend that set it apart from the other Nordic countries (Bourgeault and Wrede 2008; Wrede and Näre 2013). However, due to international recruitment and a growing number of international students, workplaces have become increasingly diverse, particularly in the health care sector. Such transnational mobility inevitably challenges the predominantly monolingual literacies in the hospital setting.

This article focuses on an international nursing student's second language documentation skills in the Electronic Patient Record (EPR) system in a hospital environment in Finland during his practical training for a degree program in nursing administered in English. Previous studies on medical communication have mostly focused on interactions between patients and health care professionals (see Candlin and Candlin 2013; Sarangi 2010) or multilingual nurses' oral skills (see Andersson 2009; Jansson 2014). There are few studies (see Nikolaidou and Karlsson 2012; Karlsson 2014) on written documents, but fairly recently computer-based practices have come under scrutiny as the "third party" in interactions within the hospital environment (see Moyer 2013; Pearce, Arnold, Phillips, Trumble and Dwan 2012; Swinglehurst, Roberts and Greenhalgh 2011). However, these practices have not yet been studied in detail regarding second language learning and use. Due to the increasing number of international workers, it is essential to examine how the language repertoires of individuals intersect with laws ${ }^{1}$ and local practices in the social action of EPR documentation. Here, documentation is explored by taking into account its social nature: workplace litera-

1 Legislation on the Handling of Patient Records (298/2009), Personal Data Act (523/1999).

*Corresponding author: Aija Virtanen, University of Jyvaskyla - Department of Languages, P.O. Box 35 FIN-40014 University of Jyvaskyla, Jyvaskyla 40100, Finland, E-mail: aija.virtanen@jyu.fi 
cies are socially constructed in a context (see Belfiore, Defoe, Folinsbee, Hunter and Jackson 2004). Documentation is an especially relevant task in the nursing profession and, at the same time, it is considered to be one of the most challenging linguistic practices in the hospital environment for international workers (Kela and Komppa 2011; Tuononen 2013; Virtanen 2013).

In this article, I examine an international student's documentation skills and agency when using the EPR with his mentor. The research questions are the following: 1) what kinds of forces constrain or afford adequate use of the EPR and how, and 2) what kinds of opportunities does the student have to practice the use of the EPR? By drawing on an ecological framework, this study opens a new perspective on the interaction between L1 and L2 speakers in the context of EPR documentation (Kramsch and Steffensen 2008; Steffensen and Fill 2014; van Lier 2004). Nexus analysis is applied as a meta-methodology to integrate the results of my previous studies and the different methodological tools used in this article (Hult 2010; Pietikäinen 2012; Scollon and Scollon 2004). Dialogical interaction analysis (Linell 1998, 2009; Suni 2008) is employed here to analyze audiorecorded documentation sequences in the EPR. Furthermore, narrative analysis (de Fina and Georgakopoulou 2012; de Fina 2014; Vitanova 2005, 2010) is applied in order to explore the subjective viewpoints of the student and his mentors. Nexus analytical concepts are used to describe the participants' historical bodies and how they are encountered in the interaction order (see Scollon and Scollon 2004). Both dialogical interaction analysis and narrative analysis help to reveal the way in which the student has positioned himself and the positioning of the student by his mentors. This study is a part of a longitudinal ethnographic study ${ }^{2}$ about international nursing students that focuses in particular on the development of their work-related Finnish language skills.

\section{Ecological perspective}

Language ecology, or ecolinguistics, is a holistic approach to exploring language and communication in context, and it brings together both dialogical and sociocultural perspectives in regards to language (Kramsch 2002; Kramsch and Steffensen 2008: 2; Steffensen and Fill 2014: 13; van Lier 2004; Vygotsky 1978). Positionings between the social world and the individual are seen as socially constructed

2 The data collection was implemented as a part of the project Finnish as a work language: A sociocognitive perspective to work-related language skills of immigrants (2011-2013, Emil Aaltonen Foundation) with funding from the Finnish Cultural Foundation (2014-2015). 
and, therefore, shaped by power relations (Kramsch and Steffensen 2008: 26). An ecological perspective enables observation of actions on both micro- and macrolevels of various timescales. In order to explore different social, historical, and power-related aspects of language, the dialogical concept of heteroglossia is taken into account. Language is not neutral: centrifugal and centripetal tensions constantly form language. The latter describes forces that unify language, and the former describes forces that tear language apart (Bakhtin 1981: 272; Blackledge and Creese 2014: 7; Dufva, Suni, Aro and Salo 2011). The laws regarding the use of a standard language in reports can be seen as a unifying tension, and, conversely, dialects and different varieties of language can be viewed as disunifying tensions. These forces highlight the intertextuality of language: participants are in a dialogue with specific texts or genres in situ (Linell 2009: 53). In other words, students encounter not only the Finnish language, but varying documentation practices to which they bring their own historical bodies as second language users.

Even though our words and language are full of other people's voices and meanings, the dialogical approach does not deny the existence of one's own agency (Linell 2009; Vitanova 2005: 154-155). In applied linguistics, agency is considered to be the "socioculturally mediated capacity to act" (Ahearn 2001: 112). An individual has his or her own mixture of voices that can be used for his or her own purposes. Individuals are able to effect the achievement of their own goals, perform and construct new identities, and actively resist some given positions (Duchêne, Moyer and Roberts 2013: 7; Duff 2012: 417; Linell 2009: 112). However, socioeconomic, cultural and economic factors can limit actual choices and opportunities to exercise agency. Hence, agency is linked to power: individuals with a stronger sense of agency may have better success in achieving their goals. Instead of the dichotomy of powerful versus powerless, power relations are considered to be dialogically interconnected and dynamic (Duff 2012: 417; Linell 2009: 216-217). As newcomers, international nursing students are faced with these power relations and positionings in the workplace.

From an ecological perspective, agency is seen as a social event that involves initiative, engagement, and consciousness of the consequences of one's own action (van Lier 2004). Agency promotes the perception of opportunities to act. It also relates to the concept of affordance. The definition of affordance was first suggested by Gibson (1977) and later developed by van Lier (2004), who argues that the environment is perceived differently depending on what one considers meaningful. Affordances allow action and learning potentials, and they drive individuals to act (van Lier 2000: 252, 2002: 146, 2004: 62-63). 


\section{Framing the research problem through nexus analysis}

Workplace literacies are forms of social action in specific contexts that are learned by participating in practices with the other members of a community. At the same time, participants reproduce and co-construct practices by being a part of them; power relations are constantly reshaping texts within a given community (Belfiore et al. 2004; Barton and Hamilton 2012; Golden and Lanza 2012; Nikolaidou and Karlsson 2012). This article looks beyond text to explore the embedded meanings and social nature of the Electronic Patient Record documentation process in a Finnish hospital.

EPR documentation was identified as a research problem by applying nexus analytical guidelines (Scollon and Scollon 2004). Nexus analysis can be considered as a suitable tool from an ecological perspective because it aids in the understanding of social action and its circulating resources, such as large-scale discourses and historical trajectories, instead of focusing exclusively on either the micro- or macro-level. It combines various methods, such as ethnography, critical discourse analysis, and interactional sociolinguistics (Hult 2010: 10; Pietikäinen 2012: 418, 434; Scollon and Scollon 2004). Nexus analysis is not a method in itself, but rather a meta-methodology for combining different methodological tools and one's previous studies in an ethnographic study (Hult 2010; Pietikäinen 2012; Scollon and Scollon 2004).

In nexus analysis, circulating elements that intersect in a social action are divided into discourses in place, historical body, and interaction order. Discourses in place can be seen as circulating through action. They may become internalized as part of historical bodies through an individual's lived and accumulated experiences. The definition of an interaction order comes originally from Goffman (1983). Later developed by Scollon and Scollon (2004), it refers to a typical social setting or arrangement that can vary, depending on different social circumstances. A social action occurs within a site of engagement. When a unique site of engagement is regularly revisited, it is referred as a nexus of practice (see Scollon and Scollon 2004: 12-14, 19, 153-155.)

As indicated earlier, the current study is part of a larger ethnographic longitudinal case study on the development of international nursing students' workrelated Finnish language skills. In order to identify the focus of the current study, I used a triangulation of data from my previous studies on beliefs about workrelated language skills, as observed in media discussions (Virtanen 2011), and work-related narratives of international nursing students (Virtanen 2013). Figure 1 illustrates this research process. 


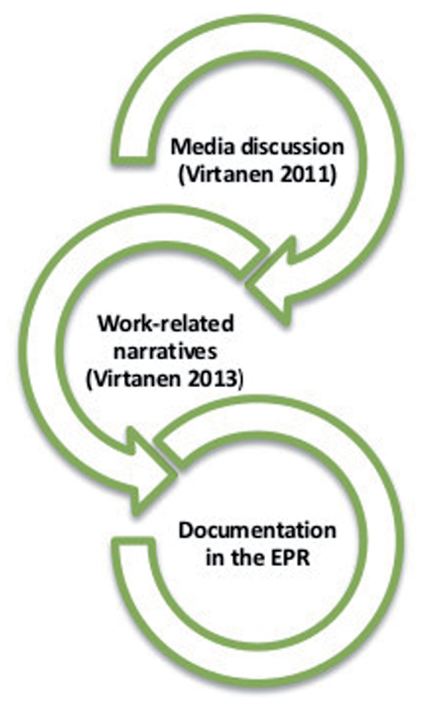

Figure 1.: Previous studies and the research process.

The findings of my previous study (Virtanen 2011) on media discussions related to the mobile workforce in the health care sector led me to focus on beliefs about professional language skills. International nurses were shown to be positioned as isolated units, and language learning was seen as an individual struggle. Moreover, international nurses' professional skills were questioned because their Finnish language skills were assumed to be insufficient (Virtanen 2011). After framing the beliefs surrounding the international workforce, I took a closer look at the work-related narratives of focal participants - international nursing students $(n=4)$ and their mentors $(n=6)$ - and the interplay between agency, identity, and motivation (Virtanen 2013). The narratives examined were related to the students' future hopes and fears, and to their practical training experiences. In terms of the professional skills necessary in a hospital environment, documentation in Finnish was seen as a major obstacle for international nursing students seeking to gain access to the labor market after completing their studies (Virtanen 2013: 410). This previous research led me to take a closer look at documentation practices and to focus on EPR documentation as a repeated site of engagement, that is, as a nexus of practice.

As a crucial facet of the hospital workplace's literacies, EPR documentation guides practices. Both multilingual international students and other (Finnish) members of the work community face the challenge of changing workplace literacies due to a "new work order", including new technologies and more 
textualized work environments (Gee, Hull and Lankshear 1996; Karlsson 2014; Nikolaidou and Karlsson 2012). For instance, due to criticisms of the time-consuming nature of the oral reporting tradition, there has been a tendency to move gradually towards electronic patient records instead (Valta 2013). There are a few studies on Finnish report documents (see Haapakorpi and Haapola 2008; Tiililä 2011), yet some are related to the use of EPRs (see Häyrinen, Saranto and Nykänen 2008; Karvinen 2009; Valta 2013). When it comes to language use in EPRs, different language varieties face the formal regulations for written documentation. There are rules for how patient records should be handled (MSAH 2012) and guidelines for proper language use (see Laaksonen, Kääriäinen, Penttilä, TapolaHaapala, Sahala, Kärki and Jäppinen 2011). Moreover, varying language backgrounds inevitably have an effect on the language used.

\section{Data and methods}

\subsection{Data}

In the current study, the analysis focuses on one informant, Daniel, a student in a nursing degree program in Finland. Administered in English, this program is designed for both Finnish and international students. It includes one compulsory Finnish course (3 ECTS) ${ }^{3}$ and other optional Finnish language courses. Nevertheless, students perform their practical training periods in a mostly monolingual Finnish-speaking hospital environment, although they have the right to receive guidance in English.

Daniel's motivation to come to Finland from Kenya was due to Finland's reputation as a country with free, high-quality education. Before he applied for a nursing program, he studied medical laboratory science in Kenya. He has lived in Finland since he started his studies at a university of applied sciences in 2010. At the beginning of my data collection, I observed students' vocational and Finnish classes in order to map the focal actions and participants. A two-year follow-up began when Daniel was 24 years old and his second year as a student was about to start. It concluded at the end of his third year of studies, just after his last practical training. The data discussed in detail below are part of a larger set of ethnographic data that I collected: a two-year media follow-up related to the international workforce in the health care sector, interviews with 13 international nursing students and seven of their vocational or Finnish language teachers, and

3 European Credit Transfer and Accumulation System. 
classroom and workplace observation. Some of this data has already been analyzed in my previous studies (see Figure 1 above). Table 1 summarizes the data examined in this sub-study. For ethical reasons, all names are pseudonyms.

Table 1: Description of the data.

\begin{tabular}{|c|c|c|c|}
\hline Round & Participants & Data & $\begin{array}{l}\text { Length } \\
\text { (minutes) }\end{array}$ \\
\hline Round 1, July 2011 & Daniel \& researcher & $\begin{array}{l}\text { Interview: initial } \\
\text { mapping }\end{array}$ & $47: 10$ \\
\hline Round 2, November 2011 & $\begin{array}{l}\text { Daniel, researcher \& } \\
\text { researcher } 2\end{array}$ & Interview & $46: 41$ \\
\hline \multirow[t]{2}{*}{$\begin{array}{l}\text { Round 3, January } 2012 \\
2^{\text {nd }} \text { practical training period }\end{array}$} & Daniel \& Kati (mentor) & $\begin{array}{l}\text { Interaction: } \\
\text { Documentation in the } \\
\text { EPR }\end{array}$ & $15: 37$ \\
\hline & Kati (mentor) \& researcher & Interview & $25: 57$ \\
\hline \multirow[t]{6}{*}{$\begin{array}{l}\text { Round 4, October } 2012 \\
4^{\text {th }} \text { practical training }\end{array}$} & Daniel \& Hanna (mentor) & $\begin{array}{l}\text { Interaction: } \\
\text { Documentation in the } \\
\text { EPR }\end{array}$ & $15: 32$ \\
\hline & Daniel \& researcher & $\begin{array}{l}\text { Interview: reflection } \\
\text { upon documentation } \\
\text { interface }\end{array}$ & $15: 49$ \\
\hline & $\begin{array}{l}\text { Hanna (mentor) \& } \\
\text { researcher }\end{array}$ & $\begin{array}{l}\text { Interview: reflection } \\
\text { upon documentation } \\
\text { interface }\end{array}$ & $13: 48$ \\
\hline & Daniel \& Hanna (mentor) & $\begin{array}{l}\text { Interaction: } \\
\text { Documentation in the } \\
\text { EPR }\end{array}$ & $19: 45$ \\
\hline & Daniel \& researcher & $\begin{array}{l}\text { Interview: reflection } \\
\text { upon documentation } \\
\text { interface }\end{array}$ & $21: 45$ \\
\hline & Patrik (mentor) \& researcher & Interview & $35: 56$ \\
\hline Round 5, May 2013 & Daniel \& researcher & Final interview & $1: 17: 41$ \\
\hline
\end{tabular}

The analysis in this study focuses on semi-structured interviews with the student and three of his mentors, including three audiotaped work tasks presented in Table 1. First, the semi-structured interviews with Daniel dealt with topics related to his learning and use of the Finnish language during his practical training and studies. Second, audio recordings of interactions during EPR documentation and all interviews with the mentors were carried out during his practical training. During the aforementioned work tasks, Daniel used the EPR under the mentor's 
guidance in Finnish, discharging a client after treatment and reporting on daily routines. Mentoring is a part of the nursing profession, but usually only those mentors who feel that they have sufficient English language skills will work with international students. The challenge is that most patients are Finnish speakers who have the right to receive care in their mother tongue. Additionally, all of the professional practices, such as documentation, are in Finnish. My presence as a researcher may have had an effect on the research setting. Research is always based on a voluntary relationship between the researcher and participants, and this relationship is affected by different factors, such as age, gender, and power relations (see also Pietikäinen 2012: 416). Instead of working together with his mentor, Patrik, with whom he was used to speaking in English, Daniel did his reports with another nurse with whom he would speak mostly in Finnish. Upon my arrival in the ward, the staff already knew that my research was about Finnish language learning at work. This information might have led them to consciously organize in advance a setting where Finnish was used. However, students may have different mentors, depending on the shift. The permission for the audio recordings and the interviews were agreed upon together with the participants and the director of the ward. The research permissions were signed beforehand at institutional and individual levels. The participants had a right to withdraw from the study at any time. For ethical reasons, interactions with patients were not included in the data, and the observations focused only on student-mentor interaction. For these same reasons, screenshots of the EPR were not included.

The documentation sequences, as well as the mentors' and Daniel's reflections on the observed work tasks, are the focus of this study. The interaction data were transcribed using the conversation analysis notation system (see Kurhila 2006: 7-8). The excerpts of the interaction data are presented on three lines: the first line in Finnish, the second with glossing (see Appendix 1), and the third line with an English translation. There were obvious difficulties in translating the Finnish language examples into English. Differences in the morphological structure of the two languages makes it difficult to express the features of the nonnative Finnish spoken by Daniel, but the glossing draws attention to the key factors of the interaction sequences. The interviewees had a chance to choose between Finnish, English, and their mother tongue. Daniel chose Finnish during his practical training and English outside the hospital environment. A possible explanation for this might be that Daniel was used to speaking Finnish at the hospital, but the language of his social networks was mainly English. Interviews with Daniel's mentors - Hanna, Kati, and Patrik - were conducted during Daniel's practical training. The language used with the mentors was Finnish, the mother tongue of Hanna and Kati. Patrik had earlier gone through the same degree program as Daniel, and he also had a multilingual background. 


\subsection{Methods}

Applying nexus analysis as a meta-methodology can offer a more holistic perspective on data than the micro-level CA or CDA that traditionally focuses on the larger scale discourses (see also Pietikäinen 2012). Moreover, the researcher can choose the parts of nexus analysis that he or she finds useful for the study (Pietikäinen 2012: 419). In this study, I apply Scollon and Scollon's (2004) concepts of discourses in place, historical body, and interaction order. In order to shed light on the historical bodies of the participants, I explore the centripetal and centrifugal forces indicating discourses in place, positions set in interaction pointing to interaction order, and reflections on the documentation sequences. All these elements intersect in EPR documentation, which is a nexus of practice of this study. I combine dialogical interaction analysis (Linell 2009; Suni 2008) when analyzing documentation sequences and narrative analysis (de Fina 2014; de Fina and Georgakopoulou 2012; Vitanova 2005, 2010) when examining reflections upon documentation. Both actions in situ and narratives offer insight into locality and socio-historical context, and they also provide an opportunity to examine global discourses circulating through the social action of documentation.

First, the interaction data are analyzed by applying the dialogical approaches taken by Linell (2009) and by Suni (2008): the focus is on shared linguistic resources and on the co-construction of knowledge in negotiation sequences. I take a closer look at communicative projects (CPs) emerging in the sequences. Some of the CPs are local and some of them more far-reaching: they develop in a dialogue that is open-ended, dynamic, and multi-functional, but end with joint accomplishment. (Linell 2009: 194, 196, 1998: 218.) Second, interaction data are analyzed using the concept of heteroglossia: what kinds of unifying and disunifying forces of language emerge in the interaction and how? Third, both the student's and the mentors' reflections on the work tasks are analyzed by applying narrative analysis, following de Fina and Georgakopoulou (2012) and Vitanova (2005, 2010). The narratives examined are not only the voices of the interlocutors, but the voices of others: how the interlocutors make the words their own, that is, how they "sign their own acts of authoring" (Vitanova 2005: 156, 2010: 30). Narratives provide an opportunity to examine how narrators position themselves in relation to others and the rest of the social world (de Fina and Georgakopoulou 2012; de Fina 2014). Fourth, both of the methods enable examine agency and the positionings that have been established. 


\section{Results}

\subsection{Constraining and affording forces}

In this section, the focus is on the interplay between power and agency, that is, the factors that help or hinder the appropriate use of the EPR. The audio recordings took place after Daniel had been one week in the ward for patients with mental disorders and alcohol abuse. Daniel sat at the computer and his mentor, Hanna, sat on his left side in a chair facing the screen. I was present as well, observing the situation from behind. Hanna had not mentored international students before, and this was the first time for her and Daniel to use the EPR together. Daniel's gaze was mostly focused on the screen and on the keyboard, while Hanna's gaze alternated between Daniel and the screen. This first excerpt of reporting on daily routines highlights how Hanna and Daniel positioned themselves and one another in the roles of mentor and student, as well as how affordances were perceived and utilized.

Excerpt 1.

(1) $\mathrm{H}$ tota (.) tuolla on pieni kirjoitusvirhe? ((pointing at the screen)) PRT there-ADE be.3SG small spelling mistake 'er (.) there is a small spelling mistake?'

(2) D joo?

'yeah?'

(3) $\mathrm{H}$ *väärin[päin ne kirjaime-t* wrong way those letter-pl “*the wrong way around ${ }^{\star \star}$

(4) D joo? joo? l joo yeah yeah yeah can-2SG correct-INF me-PAR 'yeah? yeah? yes you can correct ${ }^{\star} \mathrm{me}^{\star}$ '

(5) $\mathrm{H}$ joo? joo? va-] 'okay? okay? cho-'

(6) $\mathrm{D}$ mi-täs mä voi-n kirjoitta-a. what-PAR I can-1SG write-INF 'what shall I write.'

(7) $\mathrm{H}$ oota, wait.IMP 'wait,'

(8) D sui-suiku? 'shower?'

(9) $\mathrm{H}$ suih? (.) ensin tule-e h:h. [sitten tule-e vasta $k: k$. first come-3SG $h$ then come-3SG PRT $k$ 'suih? (.) at first then there is h:h and after it k:k.'

(10) D joo okei. 'yes okay. 
(11) $\mathrm{H}$ suihku-ssa käy-nyt? (.) ja sitte (.) osallistu-i ja >sit shower-INE go-PPC and then participate-PST.3SG and then

(12) vo-isi-t kirjotta-a siihe vielä< että can-COND-2SG write-INF there-ILL PRT that

(13) pesu-i-hin osallistu-i.

washing-PL-ILL participate-PST.3SG

'been in the shower? (.) and then (.) participated and >then you could write there< that participated in washing.'

(14) D joo:o. ((typing $10 \mathrm{~s})) \quad[(-)$

'okay. $\quad\left[(-)^{6}\right.$

(15) $\mathrm{H} \quad>$ sie-ltä] puuttu-u $u: u,<(2.0)$ sui, (.) hyvä? (2.0) there-ABL lack-3SG u good

'> u: $\mathrm{u}$ is missing, < (2.0) sui, (.) good? (2.0)'

(16) sitte (.) to-hon voi laittaa väli-n? ((pointing at the screen)) then there-ILL can put space-GEN

'then you can add a space there?'

(17) $\mathrm{D} \quad \mathrm{mm}$ ?

(18) $\mathrm{H}$ se on helpo-mpi sitten luke-e(.) ja mi-hin sit be.3SG easy-COMP then read-INF and what-ILL $s$

(19) laito-i-tte $=k s$ te perusrasva- $a$. put-PST-2PL=Q you.2PL basic lotion-PAR 'it 's easier to read that way (.) and where s- did you put basic lotion.'

(20) D (1.0) me jalo-i-[lle, we foot-PL-ALL

'(1.0) we put on feet,'

(21) $\mathrm{H}$ joo.] 'okay.'

(22) D ja, 'and,'

(23) $\mathrm{H}$ mut ol-i=ks se vaan tavallista rasvaa-a vai but be-PST.3SG=Q it just general lotion-PAR or

(24) lääkerasva-a. medicine lotion-PAR 'but was it just general lotion or medicine lotion.'

(25) $\mathrm{D}$ se ol-i(.) normaIt be-PST.3SG norma'it was (.) norma-‘

(26) H varmaan [perus, 'probably [basic,'

(27) D jootavall- ] joo 'yeah gener- ] yeah'

(28) $\mathrm{H}$ joo, >sit sii-hen voi kirjotta-a vielä< perusrasva. okay then there-ILL can write-INF PRT basic lotion 'okay, >then you can write $<$ basic lotion there.'

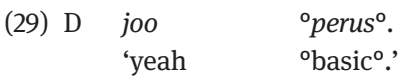


Roughly speaking, four jointly accomplished communicative projects can be seen: lines 1-5, 6-18, 18-21, and 23-29. The first local communicative project, negotiation about roles (lines 1-5), starts with Hanna's nested modification project (line 1). The interlocutors do not know each other very well: Hanna hesitates to edit Daniel's spelling and when she does, she does so in a delicate manner: "er there is a small spelling mistake" (line 1). Daniel accepts this positioning as a student by encouraging Hanna with laughter in his speech to edit his language, "you can correct me” (line 4). The project ends with Hanna's approval (line 5) and, thereafter, she modifies Daniel's suggestions. These positionings emerging from the interaction order lead us to agency: agency is coconstructed and co-developed, as well as constantly in motion (see also Lantolf and Thorne 2006: 238; Moyer 2013: 198-199). This dynamic nature of agency is evident when Daniel starts a new communicative project and he asks what $I$ should write, instead of we should write, indicating his activity and his own voice (line 6). Suiku 'shower' (line 8) is an answer to Daniel's own question (line 6). This suiku with a rising intonation anticipates either modification or approval. Hanna reacts by starting a modification project (line 9-18) while Daniel types and approves (lines 10,14,17). Hanna starts a new project to find a mutual understanding about where te 'you, plural' put basic lotion (lines 18-21). Daniel answers me jaloille 'we put on feet' (line 20), referring to himself and the patient as agents. Hanna ends this communication project with an approval joo 'okay' (line 21). On line 22, Daniel tries to start a new topic or add something by saying ja 'and', but Hanna ignores this turn and instead asks what kind of lotion was put on the patient's feet (23-24). This turn indicates the power that Hanna has as a mentor.

Power relations are presented as far as standard language and terminology intersect in a site of engagement. This is evident when Daniel searches for the correct word for "basic lotion" in the last communication project (lines 23-29). He suggests normaali 'normal' (line 25) and tavallinen 'general' (line 27), but eventually writes and repeats Hanna's word perus 'basic' (line 29). The interaction data include a significant amount of repetitions, especially reduced repetitions, that are focused on various phonemes of the word (lines 9, 15; see Suni 2008: 85). Repetition is crucial not only in terms of second language learning (see Kurhila 2006; Lilja 2010; Suni 2008), but it also helps to ensure mutual understanding through the use of words that resemble others as much as possible, since nurses in the following shift need to know what happened in the previous shift. These discourses in place, which Hanna echoes and Daniel repeats, indicate that literacies are socially constructed. This heteroglossic nature of language represents both disunifying and unifying forces: Daniel's words deconstruct the standardized language, while Hanna's voice echoes 
standard language use. While Daniel utilizes affordances by accepting and rewriting Hanna's suggestions (lines 2, 10, 14, 17) and repeating Hanna's words (line 29), he still struggles with documentation. In particular, the words suiku 'shower' (line 8) and pesuihin 'in washing' (line 14-16) seem to be difficult for him to write: he requires a significant amount of scaffolding in order to perform the task (see Vygotsky 1978: 86). Hanna gives him time to type and she only makes modifications afterwards. She offers affordances and chances for participation by pointing (lines 1, 16), providing feedback (lines 1, 3, 15-16), suggesting what to write (lines 11-13, 28), and offering other various options (lines 2324). Daniel positions himself as an active participant when he utilizes affordances by asking more questions and suggesting what to write (line 6, 8). Perceiving these affordances indicates his agency (van Lier 2004). Hanna has the power of a mentor and native speaker to approve the final written form (lines 11-13, 28). This pattern indexes the power relations that emerge from the interaction order.

In the next excerpt, which comes from the interview that took place after the documentation sequence, Daniel reflects upon his experience. It illustrates Daniel's frustration and the challenges he perceives while he reports, such as regarding the structure of the language:

Excerpt 2. Interview with Daniel (translated).

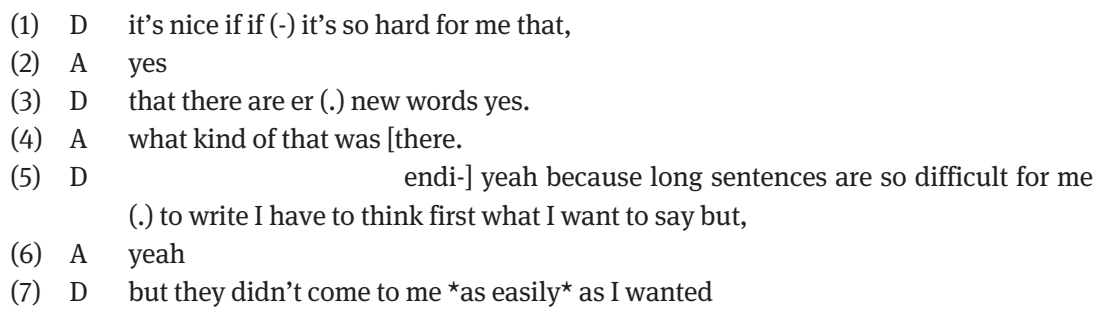

As the above discussions shows, Daniel has not yet been socialized into documentation and he has not appropriated discourses in place which is present, for instance, as a struggle to find correct words. Furthermore, among international nursing students, reporting is considered, linguistically, to be the one of the most demanding work tasks (Kela and Komppa 2011: 185; Virtanen 2013: 410). This difficulty is shown throughout the interaction data whenever Daniel asks for help with dictation, modifications, repetitions, questions, and clarification requests (see excerpt 1). Hanna is willing to offer him these affordances as well. Even though Daniel himself is frustrated and quite critical in terms of his Finnish language skills, Hanna's describes Daniel and his Finnish language as follows: 


\section{Excerpt 3. Interview with Hanna (translated).}

((a laugh) $) \star^{\star}$ maybe the Finnish language ${ }^{\star}$ is not the easiest one so (.) but I didn't feel in any way like oh my *he doesn't understand to add two e's or t's or* ((laughing)) [- - ] when he has courage so he has courage to try and do (.) so he is not like you should *tell me everything now $^{\star}$

Based on the whole data set, Daniel is positioned by his mentors as a motivated and adept language learner and student. Instead of drawing attention to the limitations of Daniel's less-than-perfect Finnish language skills, Hanna reiterates the difficulty of the Finnish language, which can be considered to be a common truth (see Virtanen 2011: 167). Even though Daniel only had a few opportunities to report, he was engaged in his tasks because of the future: "I did enjoy when given the opportunity to try and write (.) that's actually what has helped me in the future to try and write because of I kind of write some reports so it's really giving me some courage (.) of course I need more of that." The scenario as a part of his historical body has motivated him, encouraged him, and supported engagement in this particular work task (see Murray 2011: 79-80; Virtanen 2013: 421). In contrast, Patrik states that Daniel seems to be a bit unsure about his Finnish language skills: "I don't dare to give more responsibilities to him(.) yeah(.) and even though I said that his basic language skills are quite ok or good(.) he is unsure about it when it comes to a more demanding situation." This positioning may have an effect on access to situations where agency and documentation skills could be developed and where a student could learn to work independently. This positioning is evident in Kati's statement, too: "if we have a Finnish student they are completely independent [- -] but if there is an international student the mentor has to be next to him all the time." The problem is combining the student's right to guidance in English and the demand for work tasks that require Finnish language skills. The differing positionings between international and local students may increase inequalities in terms of their access to the Finnish labor market.

\subsection{Opportunities to appropriate multivoiced documentation in the EPR}

This section focuses on the multivoicedness of EPR documentation, as well as on the opportunities afforded to the student to practice use of the EPR. Discourses in place from different time-scales circulate through a site of engagement, but the language of the documenting in the EPR is still specific and influenced by normativity. This heteroglossia is evident in the next excerpt where Hanna and Daniel 
document how a patient was taken to be washed in the morning with the shower wheelchair:

Excerpt 4.

(1) H sit sä vo-isi-t vähän kirjat-a et miten te te-i-tte then you can-COND-2SG little write-INF that how you.2PL do-PST-2.PL

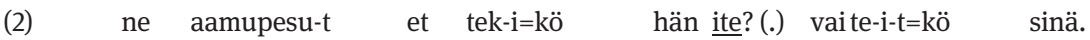
these morning wash-PL that do-PST.3SG=Q he himself or do-PST.2SG=Q you 'and then you could write a bit about how did you do the morning washing like did he do it by himself? (.) or did you do.'

(3) D (.) $\mathrm{mm}($.$) minä.$

'(.) $\mathrm{mm}($.$) I.'$

(4) $\mathrm{H}$ nii.

'yes.'

(5) D (3.0) voi-n kirjoitta-a aute-ttu-na vai?

can-1SG write-INF help-PPPC-ESS or

(3.0) 'I can write with help right?'

(6) $\mathrm{H}$ voi kirjoitta-a aute-ttu-na joo kyllä?

can.3SG write-INF help-PPPC-ESS yeah yes

'you can write with help uhuh right?'

((Daniel typing 3.0 seconds))

(7) H <aute-ttu-na.>(.) kaks ${ }^{\star}$ t:tä* (.)^hankala-a varmaan kun on niin paljon*, help-PPPC-ESS two t-PAR difficult-PAR maybe when be.3SG so much '<with help.>(.) two *t's* (.) ${ }^{\star}$ it must be difficult because there's so much ${ }^{\star}$ '

(8) D mm, (2.4) ${ }^{\circ}$ on-ks $\mathrm{se}^{\circ}$.

$\mathrm{mm} \quad$ be.3SG $=\mathrm{Q}$ it

'mm, (2.4) ${ }^{\circ}$ is it ${ }^{\circ}$.'

(9) $\mathrm{H}$ joo.

yeah.

(10) D ${ }^{\circ}$ autettuna ${ }^{\circ} . h(.) \quad{ }^{\circ}$ autettuna ${ }^{\circ}$

help-PPPC-ESS help-PPPC-ESS

'owith help ${ }^{\circ} . h(.){ }^{\circ}$ with help ${ }^{\circ}$ '

(11) $\mathrm{H}$ (1.3) ja mi-ssä te te-i-tte ne $\mathrm{ku}$ häne-lle and where-INE you.2PL do-PST-2PL them when he-ADE

(12) on teh-ty aikasemm-in vuodepesu-ja mutta nyt=hän be.3SG do-PPPC early-ADV sponge bath-PAR.PL but now=PRT

(13) me ei ol-tu sii-nä tai te e-tte ollu we NEG be-PPPC there-INE or you.2PL NEG-2PL be-PPC

(14) sii-nä vuotee-ssa et voi-t laitta-a että suihkutuoli-lla there-INE bed-INE that can-1SG put-INF that shower wheelchair-ADE avuste-ttu niinku vessa-an, help-PPPC like restroom-ILL

'(1.3) and where did you do it 'cause (s)he has had sponge baths before but we weren't there or you weren't on the bed so you can put that (s)he was taken to the restroom with a shower wheelchair,' 
(16) D mm. (4.5)

'mm.' (4.5)

((Daniel typing 11 seconds))

(17) $\mathrm{H}$ joo? (.) suihkutuoli-lla vessa-an men-ty ${ }^{4}$ vaikka voi-t kirjotta-a okay shower wheelchair-ADE restroom-ILL go-PPPC PRT can-2SG write-INF

(18) niin.

so

'okay? (.) restroom was visited with a shower wheelchair you can write like that.'

((Daniel typing 7 seconds))

(19) D suihkutuoli-lla, (2.5) men-nyt vessaan.

shower wheelchair-ADE go-PPC restroom-ILL

'with a shower wheelchair, (2.5) he went to the restroom.'

(20) H joo,

'yeah,'

((Daniel typing 7.3 seconds))

(21) $\mathrm{H}$ tai men-ty. (.) ${ }^{\circ}$ voi-t kirjoitta- $\mathrm{a}^{\circ}$. (2.0)

or go-PPPC can-2SG write-INF

'or was visited. (.) ' $\mathrm{you}$ can write ${ }^{\circ}$. ' (2.0)

((Daniel typing 4.0 seconds))

(22) D men-ty?

go-PPPC

was visited?

(23) $\mathrm{H} \quad\langle\underline{\text { men-ty }}\rangle$. (.) vielä y:y. men-ty.

go-PPPC PRT y go-PPPC

'< $\underline{\text { was visited }}>$. add y:y. was visited.'

(24) D ahaa?

'okay?'

(25) $\mathrm{H}$ noin. (2.0) sitte?

'that's right. (2.0) then?'

The sequence above illustrates key factors of the language of documentation. Written reports direct practices and it is therefore crucial that they are understood without any misinterpretations between shifts. Two local communicative projects (Linell 1998: 218, 2009: 194, 196) can be seen: negotiation on who has done what (lines 1-10) and where (lines 11-25). These projects include smaller sequences: lines 1-4, 5-10, 11-16, and 17-25. First, Hanna wants to know whether the active agent has been Daniel or the patient (line 2). Daniel positions himself in an active role by answering minä 'I' (line 3). Hanna approves this by saying niin 'that's right' (line 4) and, at the same time, she closes the sequence. Second, Daniel starts a new sequence by suggesting a phrase to write down (line 5). This turn indicates that Daniel knows the phrase autettuna 'with help' (line 5), but he is

4 Menty does not express a person; it is literally a passive form. 
unsure whether he can use it in this specific context. On line 6, Hanna approves Daniel's suggestion. After a while, Hanna realizes that Daniel needs scaffolding in order to write down the word autettuna 'with help' and she offers the support needed by helping with typing and starting a modification project (line 7). Simultaneously, Hanna aligns herself with Daniel: she sees the Finnish language through Daniel's eyes when she points out the difficulty of spelling (line 7). Hanna can sense Daniel's frustration and she wants to make him feel at ease, a desire that can be heard in her tone of voice as well. Daniel types the word and he wants to make sure it is correct by asking feedback from Hanna: onks se 'is it' (line 8). Similarly, as in excerpt 1, Daniel quietly repeats the typed word as if to remember it better (line 10). This turn ends the first communicative project of negotiating who has done what.

The second communicative project starts with Hanna's question of where the action was done, and she answers her own question (lines 11-15). She positions herself as a passive participant by modifying me ei oltu 'we weren't' to te ette ollu 'you weren't' (line 13). Daniel approves (line 16) and he starts typing the location of showering, but after a while Hanna decides to offer a readily formulated sentence to describe the situation in a standard way where the passive voice is crucial (lines 17-18). This centripetal nature of language appears through morphological modifications (Suni 2008) that are shown throughout the sequence, with Hanna providing Daniel the standard expressions (lines 17-18, 21). Daniel's repetition is elaborated on with mennyt 'he went' (line 19). Even after approving Daniel's suggestion (line 20), Hanna makes a modification with menty 'was visited, literally: was gone' (line 21). Thus, she offers an example of how centripetal forces influence language use (see Bakhtin 1981; Dufva et al. 2011). A similar pattern repeats itself throughout the data as the institutional voice is echoed by Hanna. The passive voice is used excessively in written documents, a point that Karvinen (2009) makes when stating that it is often used when the medical practitioner is pointing to his or her own practices. The grammatical form of Daniel's own production mennyt 'he went' (line 19, past participle) indexes that the patient was the active doer. The verb form menty 'was visited, literally: was gone' (line 21, passive past participle), on the contrary, indicates that the patient did not go to the washing by himself, but that he or she was with a nurse. Hence, the passive voice is related to agency. Similarly, Daniel's suggestion autettuna 'with help' (line 5, passive past participle essive) points to a situation where the client needed help; this is mirrored by Hanna's suggestion avustettu 'helped' (line 15, passive past participle). The last sequence ends with Daniel's acknowledgment ahaa 'okay' (line 24) and Hanna's approval noin 'right' (line 25), and she starts a new topic with sitte 'then' (line 25). Both of these communicative projects were accomplished together. 
As is evident in excerpts 1 and 4, Hanna acknowledges Daniel's difficulties with typing throughout the dialogue, and she gives Daniel time to finish his sentences even though writing takes a long time. The next interview excerpt illustrates the presence of discourses in place from varying timescales in written documents. Hanna reflects on what has helped her when mentoring students and what roles others have played in the process:

Excerpt 5. Interview with Hanna (translated).

well I was thinking of the stuff the mentor back then thought important about like the practices of the ward and (.) well reporting here has got a huge role it's so important, and that you can only learn when you do it (.) 'cause if you write nothing the night shift they've got no idea what to do (.) the patients can even be familiar to you (.) so it's like like (.) every day is a pretty different [- - ] so I've just been thinking like what's like(.) important to me and been thinking the ways others've been mentoring students and that's kind of a way to learn (.) a little or so

The voices of not only the participants but also of some others, such as Hanna's mentors, have become part of Hanna's historical body: she has appropriated these discourses in place. She emphasizes that documentation practices are only learned by doing at the workplace. Her beliefs about good mentoring practices are thus a result of appropriating the voices of others (see Vitanova 2005: 156). Hanna performed her own practical training in the same organization and she positions her own mentor as the resource for learning crucial practices of the ward, such as documentation: "I was thinking of the stuff the mentor back then thought important.” The knowledge is co-constructed as well. Literacies are thus embedded in the whole social and physical work environment (see Jackson 2004: 4-5). When using the EPR, others are present as recycled past experiences and as an expected audience, too: "because if you write nothing the night shift they've got no idea what to do" (see also Blackledge and Creese 2014: 10). The EPR inevitably becomes a multivoiced third party that mediates information between the workers (see Moyer 2013: 214; Swinglehurst et al. 2011: 7, 12). Because literacies are embedded in the work environment, the individual becomes socialized into them through participation (see also Duff and Talmy 2011: 96-97), as Hanna's statement illustrates: "you can only learn when you do it." In the next excerpt, Daniel describes his experience on observed action and his opportunities to participate:

Excerpt 6. Interview with Daniel (translated).

(1) D: ((sighs)) well, it's like I think ok if I can do (.) do this every day if I've got so much practice if we got the same same training at school if we had [the EPR] course and so (.) what we can write (.) but (.) *we ain’t got it* ((a laugh)) I've got to study it all when doing practical training and nurses hasn't haven't got time to wri- to say say to us what 
what we've got to write and (.) correct everything what (-) 'cause when I'm writing I (.) I need so much to correct (-) and (.) ${ }^{\circ}$ yeah $^{\circ}\left(\right.$.) I’m not yet can’t * write $^{\star}(($ a laugh))

(2) A: ((a laugh))

(3) D: alone

Daniel expresses that he does not have enough opportunities to practice documentation. In the final round of interviews, Daniel emphasizes that helping international students with EPR documentation is extra work for nurses: "it's the time they have to create for the students." This result aligns with Tuononen's (2013) study on international practical nurses in Finland. International students having to ask for help takes away time from the duties of their mentors. It is quite time-consuming to mentor these students, compared to those for whom Finnish is their first language. Daniel describes this, aligning himself with the nurses: "if they see that you're really struggling with the language then it becomes a bit of a challenge also for them" (see also Vitanova 2005: 157). Hence, learning the necessary Finnish language skills is usually the student's own responsibility: "I've got to study it all when doing practical training" (see also Virtanen 2011). As a researcher whose research interest is related to Finnish language development, I had an influence on the research setting. Some special arrangements were suggested by the mentors, even though I tried to convince them that nothing was required on my account. However, the researcher can affect the nexus of practice and transform new practices (Scollon and Scollon 2004: 178). Interestingly, the staff seem to know what would be good for the student in order for him or her to use and learn the language, but these practices are not yet part of the everyday practices of the ward.

\section{Conclusions}

The purpose of this study was to explore an international nursing student's documentation skills and agency when using the Electronic Patient Record (EPR) together with his mentors. Drawing on an ecological perspective, the focus was on the forces that constrain or afford adequate use of the EPR, as well as on the opportunities that the student has to practice the use of the EPR. The roles of the student and mentors were considered in order to explore the positions established in EPR documentation, in addition to the interlocutors' reflections on them. Nexus analysis as a meta-level methodology served to define EPR documentation as the focus of the study, and it helped to combine the multiple methods and findings of my previous studies.

The dialogical analysis of interaction data and narratives shed light on the multivoicedness of workplace literacies. In order to learn workplace literacies, 
participation plays a crucial role: one learns by doing. Literacies are also embedded throughout the hospital environment. They are socially constructed and constantly changing. This finding is in alignment with the research on workplace literacies done by Belfiore et al. (2004) and Nikolaidou and Karlsson (2012). The EPR can be viewed as a multivoiced third party: EPR documentation is shaped by discourses in place from different timescales - the voices of the participants and of others from the past and present - as well as by the anticipated presence of others (see also Linell 2009; Swinglehurst et al. 2011). This heteroglossic nature of workplace literacies is present when documenting brings into dialogue the participants' historical bodies: the mentor echoes local workplace literacies and the student brings to the table his or her own history as a second language user. This aspect of centripetal and centrifugal forces has not previously been scrutinized in a professional context in detail.

The documentation sequences presented a kind of ideal situation: the mentor provided scaffolding and affordances, and the student perceived and utilized them. The student was positioned as an active participant by his mentors, as well as by his own actions, with the setting emerging from the interaction order. Opportunities for EPR documenting increased the student's agency and reinforced his future in regard to nursing as a profession (see also Virtanen 2013). Nevertheless, the student did not have regular opportunities to do reports with a mentor.

The dualistic role of the hospital environment is present: hospitals take care of patients and they educate the future workforce. However, one clear result that emerged is that the health care sector is not yet prepared for socializing international students into workplace literacies. The demand for sufficient language skills and the ability to work independently are echoed insofar as EPR documentation goes, but opportunities are limited. The general lack of opportunities to practice documentation may lead to a setting where learning the necessary Finnish language skills is seen as an individual's own responsibility. This authoritative voice about language learning was mirrored in media discussions related to the international workforce (Virtanen 2011). It seems that the importance of improving language awareness does not concern the international workforce alone, but also local nurses who face the challenge of changing workplace literacies. Even though the current study was limited by a lack of access to the everyday practices of the ward, it serves as a base for creating teaching materials and techniques for second language learning in a hospital environment. It is crucial to know the key elements of the language used, such as the excessive use of passive voice; this has been reported on in previous studies (see e.g. Karvinen 2009). At this moment, the continuing power play is manifested as inequalities between international and local nursing students, because these two groups are 
positioned differently due to their language skills. Interestingly, there seems to be a conflict between work-life demands and education when it comes to established degree programs in English. Therefore, further research should be done to explore if and how international nursing students can achieve the level of independence demanded.

The mobile workforce and an increasing use of technology in the health care sector are changing the mostly monolingual literacies of the hospital environment. By means of its ecological framework, this study aimed at gaining a better understanding of the social action of EPR documentation by applying the nexus analytical approach (Scollon and Scollon 2004) to combine different methodological tools and my previous studies. This setting offers a holistic perspective to elements intersecting in the focal action: large-scale discourses, such as the demand for sufficient language skills, and the historical trajectories of language users (see Scollon and Scollon 2004.) Even though this study introduces only one case, it potentially opens up a new thread of discussion on the forces that affect the adequate use of the EPR. Workplace literacies should be examined by taking the larger socio-historical context into account in future studies. Positions established during the course of interaction could be seen as being reshaped by power and power relations (see also Kramsch and Steffensen 2008; Linell 2009) and, therefore, more general discussion on equality in the work-life between L1 and L2 speakers is needed.

Funding: Emil Aaltonen Foundation, (Grant / Award Number: '2011-2013') Suomen Kulttuurirahasto, (Grant / Award Number: '2014-2015’)

\section{Appendices}

\section{Appendix 1. Transcription}

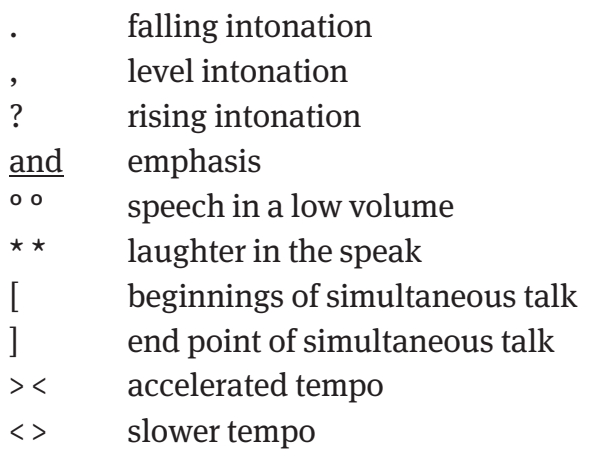


: lengthening of the sound

(.) micropause

(4.0) marks a pause in speech

(-) undecipherable talk

Mi cut-off word

.h inbreath

Glossing

GEN genitive (possession)

PAR partitive (partitiveness)

ESS essive ('as')

INE inessive ('in')

ELA elative ('out of')

ILL illative ('into')

ADE adessive ('at, on')

ABL ablative ('from')

ALL allative ('to')

Others

ADV adverb

COMP comparative

COND conditional

IMP imperative

INF infinitive

NEG negation (an auxiliary verb in Finnish)

PASS passive

PL plural

PPC past participle

PPPC passive past participle

PRT particle

PST past tense

Q interrogative

SG singular

$1 \quad 1^{\text {st }}$ person ending

$2 \quad 2^{\text {nd }}$ person ending

$3 \quad 3^{\text {rd }}$ person ending 


\section{References}

Ahearn, Laura M. 2001. Language and agency. Annual Review of Anthropology 30. 109-137. Andersson, Helena. 2009. Interkulturell kommunikation på ett svenskt sjukhus: Fallstudier av andraspråkstalare i arbetslivet [Intercultural communication at a Swedish hospital. Case studies of second language speakers in a workplace] (Skrifter utgivna av Institutionen för nordiska språk vid Uppsala universitet 77). Uppsala: University of Uppsala dissertation. http://www.diva-portal.org/smash/get/diva2:346153/FULLTEXT01.pdf (accessed 17 June 2014).

Bakhtin, Mikhail M. 1981. The dialogic imagination: Four essays by M. M. Bakhtin. Michael Holquist (eds.). Austin: Texas.

Barton, David \& Mary Hamilton. 2012. Local literacies: Reading and writing in one community. 2nd edn. London: Routledge.

Belfiore Mary E., Tracy A. Defoe, Sue Folinsbee, Judy Hunter \& Nancy S. Jackson (eds.). 2004. Reading work: Literacies in the new workplace. Mahwah, New Jersey: Lawrence Erlbaum Associates.

Blackledge, Adrian \& Angela Creese. 2014. Heteroglossia as practice and pedagogy. In Adrian Blackledge \& Angela Creese (eds.), Heteroglossia as practice and pedagogy, 1-20. Heidelberg: Springer.

Bourgeault, Ivy \& Sirpa Wrede. 2008. Caring beyond borders: Comparing the relationship between work and migration patterns in Canada and Finland. In Cecilia Benoit \& Helga Hallgrimsdottir (eds.), The Canadian Journal of Public Health 99 (Supplement 2). 22-26. http://journal.cpha.ca/index.php/cjph/article/view/1720/1905 (accessed 19 May 2014).

Candlin, Sally \& Christopher N. Candlin. 2013. Presencing in the context of enhancing patient well-being in nursing care. In Heidi Hamilton \& Sylvia Chou (eds.), Routledge Handbook of Language \& Health Communication, 259-278. London: Routledge.

Duchêne, Alexandre, Melissa Moyer \& Celia Roberts (eds.). 2013. Language, migration and social inequalities: A critical sociolinguistic perspective on institutions and work. New York: Multilingual matters.

Duff, Patricia. 2012. Identity, agency, and second language acquisition. In Susan M. Gass \& Alison Mackey (eds.), The Routledge Handbook of Second Language Acquisition, 410-426. London: Routledge.

Duff, Patricia \& Steven Talmy. 2011. Language socialization approaches to second language acquisition: Social, cultural, and linguistic development in additional languages. In Dwight Atkinson (eds.), Alternative approaches to SLA, 95-116. London: Routledge.

Dufva, Hannele, Minna Suni, Mari Aro \& Olli-Pekka Salo. 2011. Languages as objects of learning: Language learning as a case of multilingualism. Apples 5(1). 109-124.

Fina, Anna de. 2014. Enregistered and emergent identities in narrative. In Fred Dervin \& Karen Risager (eds.), Identity and interculturality, 46-66. New York: Routledge.

Fina, Anna de \& Alexandra Georgakopoulou. 2012. Analyzing narrative: Discourse and sociolinguistic perspectives. Cambridge: Cambridge University Press.

Gee, James P., Glenda Hull \& Colin Lankshear. 1996. The new work order: Behind the language of the new capitalism. Boulder: Westview Press.

Gibson, James J. 1977. The theory of affordances. In Robert Shaw \& John Bransford (eds.), Perceiving, acting, and knowing: Toward an ecological psychology, 67-82. Hillsdale: Lawrence Erlbaum. 
Goffman, Erving. 1983. The interaction order: American Sociological association. American Sociological Review 48(1). 1-17.

Golden, Anna \& Elizabeth Lanza. 2012. Narratives on literacies: Adult migrants' identity construction in interaction. In Anne Pitkänen-Huhta \& Lars Holm (eds.), Literacy practices in transition. Perspectives from the Nordic Countries, 27-53. Bristol: Multilingual Matters.

Haapakorpi, Pirjo \& Ilkka Haapola. 2008. Työn organisointi ja työhyvinvointi sosiaali- ja terveysalalla: Esimerkkinä vanhusten kotihoito [Work organization and well-being of employees in social- and health care services - the case of elderly home care]. Helsinki: Työ- ja elinkeinoministeriö. https://www.tem.fi/files/21000/TEM35.pdf (accessed 6 April 2014).

Hult, Francis. 2010. Analysis of language policy discourses across the scales of space and time. International Journal of the Sociology of Language 202. 7-24.

Häyrinen, Kristiina, Kaija Saranto \& Pirkko Nykänen. 2008. Definition, structure, content, use and impacts of electronic health records: A review of the research literature. International Journal of Medical Informatics 77. 291-304.

Jackson, Nancy S. 2004. Introduction: Reading work. In Ellen Belfiore, Tracy A. Defoe, Sue Folinsbee, Judy Hunter \& Nancy S. Jackson (eds.), Reading work: Literacies in the new workplace, 1-26. Mahwah, New Jersey: Lawrence Erlbaum Associates.

Jansson, Gunilla. 2014. Bridging language barriers in multilingual care encounters. Multilingua 33(1-2). 201-232.

Kela, Maria \& Johanna Komppa. 2011. Sairaanhoitajan työkieli - yleiskieltä vai ammattikieltä? Funktionaalinen näkökulma ammattikielen oppimiseen toisella kielellä [Nurse's language needs - standard language or professional language? Functional approach to professional second language learning]. Puhe ja kieli [Speech and language] 31(4). 173-192.

Karlsson, Anna-Malin. 2014. Writing in your own voice? Managing interpersonal meanings in elder care literacy practices. In Ann-Catrine Edlund, Lars-Erik Edlund \& Susanne Haugen (eds.), Vernacular Literacies: Past, present and future, 29-43. Umeå: Univeristy of Umeå \& Royal Skyttean Society.

Karvinen, Kati. 2009. Kotihoidon teksteillä monta tehtävää [Home care texts have many functions]. Kielikello 1/2009. http://www.kielikello.fi/index.php?mid=2\&pid=11\&aid=1981 (accessed 22 June 2014).

Kramsch, Claire \& Sune V. Steffensen. 2008. Ecological perspectives on second language acquisition and language socialization. In Patricia Duff \& Nancy Hornberger (eds.), Encyclopedia of Language and Education 8, 17-28. Dordrecht: Springer Verlag.

Kramsch, Claire. 2002. How can we tell the dancer from the dance? Introduction. In Claire Kramsch (eds.), Language acquisition and language socialization: Ecological perspectives, 1-30. London: Continuum.

Kurhila, Salla. 2006. Second language interaction. Amsterdam: John Benjamins.

Laaksonen, Maarit, Aino Kääriäinen, Marja Penttilä, Maria Tapola-Haapala, Heli Sahala, Jarmo Kärki \& Anu Jäppinen. 2011. Asiakastyön dokumentointi sosiaalihuollossa: Opastusta asiakastiedon käyttöön ja kirjaamiseen [Documentation of client work in social welfare: Guidance for writing and use of information]. http://www.thl.fi/thl-client/pdfs/d68ab232-88f c-4478-8c21-91164a177a1a (accessed 10 June 2014).

Lantolf, James P. \& Steven Thorne. 2006. Sociocultural theory and the genesis of second language development. Oxford: Oxford University Press.

Lier, Leo van. 2004. The ecology and semiotics of language learning: A sociocultural perspective. New York: Springer. 
Lier, Leo van. 2002. An ecological-semiotic perspective on language and linguistics. In Claire Kramsch (eds.), Language acquisition and language socialization: Ecological perspectives, 140-164. London: Continuum.

Lier, Leo van. 2000. From input to affordance: Social-interactive learning from an ecological perspective. In James P. Lantolf (eds.), Sociocultural theory and second language learning, 155-177. Oxford: Oxford University Press.

Lilja, Niina. 2010. Ongelmista oppimiseen: Toisen aloittamat korjausjaksot kakkoskielisessä keskustelussa [Other-initiated repair sequences in Finnish second language interactions]. (Jyväskylä Studies in Humanities 146). Jyväskylä: University of Jyväskylä dissertation. http://urn.fi/URN:ISBN:978-951-39-4116-1 (accessed 15 June 2014).

Linell, Per. 2009. Rethinking language, mind, and world dialogically. Charlotte: IAP Press.

Linell, Per. 1998. Approaching dialogue: Talk, interaction and contexts in dialogical perspectives. Amsterdam: John Benjamins.

Moyer, Melissa G. 2013. Language as a resource: Migrant agency, positioning and resistance in a health care clinic. In Alexandre Duchêne, Melissa Moyer \& Celia Roberts (eds.), Language, migration and social inequalities: A critical sociolinguistic perspective on institutions and work, 196-224. New York: Multilingual Matters.

MSAH = Ministry of Social Affairs and Health. 2012. Potilasasiakirjojen laatiminen ja käsittely: Opas terveydenhuollolle [Drawing up and handling of patient documents: Guide for health care professionals]. Tampere: Tampereen yliopistopaino. http://www.stm.fi/c/ document_library/get_file?folderld=5197397\&name=DLFE-21316.pdf (accessed 18 June 2014).

Murray, Garold. 2011. Imagination, metacognition and the L2 self in a self-access learning environment. In Garold Murray, Xuesong Gao \& Terry Lamb (eds.), Identity, motivation and autonomy in language learning, 75-90. Bristol: Multilingual Matters.

Nikolaidou, Zoe \& Anna-Malin Karlsson. 2012. Construction of caring identities in the new work order. In Charles Bazerman, Chris Dean, Jessica Early, Karen Lunsford, Suzie Null, Paul Rogers \& Amanda Stansell (eds.), International Advances in Writing Research: Cultures, Places, Measures, 507-519. Anderson, SC: Parlor Press.

Pearce, Christopher, Michael Arnold, Christine Phillips, Stephen Trumble \& Kathryn Dwan. 2012. The many faces of the computer: An analysis of clinical software in the primary care consultation. International Journal of Medical Informatics 81(7). 457-484.

Pietikäinen, Sari. 2012. Kieli-ideologiat arjessa. Neksusanalyysi monikielisen inarinsaamenpuhujan kielielämäkerrasta [Language ideologies in practice: A nexus analysis of a multilingual Inari Sámi speaker’s language biography]. Virittäjä 116(3). 410-440.

Sarangi, Srikant. 2010. Reconfiguring self/identity/status/role: The case of professional role performance in healthcare encounters. Journal of Applied Linguistics \& Professional Practice 7(1). 75-95.

Scollon, Ron \& Suzanne W. Scollon. 2004. Nexus analysis: Discourse and the emerging internet. London: Routledge.

Suni, Minna 2008. Toista kieltä vuorovaikutuksessa: Kielellisten resurssien jakaminen toisen kielen omaksumisen alkuvaiheessa [Second language in interaction: Sharing linguistic resources in the early stage of second language acquisition]. (Jyväskylä Studies in Humanities 94). Jyväskylä: University of Jyväskylä dissertation.

Swinglehurst, Deborah, Celia Roberts \& Trisha Greenhalgh. 2011. Opening up the "black box" of the electronic patient record: A linguistic ethnographic study in general practice. Communication and Medicine 8(1). 3-15. 
Steffensen, Sune. V. \& Alwin Fill. 2014. Ecolinguistics: The state of the art and future horizons. Language Sciences. 41A. 6-25.

Tiililä, Ulla. 2011. Sanoilla lavastettu virasto: Tietoyhteiskunnan arkea sosiaali- ja hoiva-aloilla [The role of language in the information society: Language in the social and health care sector]. In Marjut Johansson, Pirkko Nuolijärvi \& Riitta Pyykkö (eds.), Kieli työssä: asiantuntijatyön kielelliset käytännöt [Language at work: Linguistic practices of experts], 162-189. Helsinki: SKS.

Tuononen, Nuppu. 2013. On omat haasteet, mutta kyllä pärjää! Maahanmuuttajalähihoitajien polkuja työelämään ja kokemuksia työyhteisön jäseneksi tulemisesta [Immigrant practical nurses: Paths to working life and experiences of becoming a member of a working community]. Helsinki: University of Helsinki \& Palmenia Centre for Continuing Education.

Valta, Maija. 2013. Sähköisen potilastietojärjestelmän sosiotekninen käyttöön: Seitsemän vuoden seurantatutkimus odotuksista omaksumiseen [The sociotechnical implementation of an electronic patient record: A seven-year follow-up study from expectations to adoption]. (Publications of the University of Eastern Finland Dissertations in Social Sciences and Business Studies 62). Kuopio: University of Eastern Finland dissertations. http://epublica tions.uef.fi/pub/urn_isbn_978-952-61-1217-6/urn_isbn_978-952-61-1217-6.pdf (accessed 15 September 2015).

Virtanen, Aija. 2013. Minä sairaanhoitajana: Tulevaisuuden minuudet motivaatiota muokkaamassa [l as a nurse: Future selves making motivation]. Lähivertailuja - Lähivõrdlusi 23. 403-427.

Virtanen, Aija. 2011. Käsityksiä kansainvälisesti rekrytoitujen hoitajien ammatillisesta kielitaidosta ja sen kehittymisestä: Mediakeskusteluiden ja asiantuntijan haastattelun analyysia [Beliefs about international nurses' language skills and their development: Analysis of media discussion and an expert interview]. Puhe ja kieli [Speech and language] 31(4). 139-152. http://ojs.tsv.fi/index.php/pk/article/view/4751/4469 (accessed 21 September 2015).

Vitanova, Gergana. 2005. Authoring the self in a non-native language: A dialogic approach to agency and subjectivity. In Joan K. Hall, Gergana Vitanova \& Ludmila Marchenkova (eds.), Dialogue with Bakhtin on second and foreign language learning: New perspectives, 149-169. Mahwah, NJ: Lawrence Erlbaum.

Vitanova, Gergana. 2010. Authoring the dialogical self: Gender, agency and language practices. Amsterdam: John Benjamins.

Vygotsky, Lev S. 1978. Mind in society: The development of higher psychological processes. Cambridge, MA: Harvard University Press.

Wrede, Sirpa \& Lena Näre. 2013. Glocalising care in the Nordic Countries: An introduction to the special issue. Nordic Journal of Migration Research 3(2). 56-62. 